\title{
Towards an ethnically diverse British Methodist Church
}

\author{
Jill Marsh
}

The Revd Jill Marsh served as a Methodist presbyter in Rotherham and Leicester, UK, and is currently Director of Mission (Northampton District), undertaking parttime doctoral studies at the University of Chester.

jill.marsh51@gmail.com

Leicester, UK

Using a qualitative study of interviews with ministers who work in ethnically diverse British Methodist congregations, I explore the practices that encourage a sense of belonging together as one body in Christ and how these influence a congregation's ethos. Analysing how the respondents see their own role in this work I argue that the key challenge is the enabling of power-sharing, to which ministers contribute but which they cannot determine alone. I conclude that the decisive factor is the willingness of the members to allow the whole body to be changed by those who are 'other' and 'different'.

BRITISH METHODISM • DIVERSITY • ECCLESIAL PRACTICES • ETHNICITY • POWER-SHARING 


\section{Introduction}

Methodists in Britain have experienced significant change in their local populations in recent decades. ${ }^{1}$ Due to global migration it is much more likely than in previous generations that the Methodist churches in our cities, towns and, increasingly, our villages, will have visitors, members, and often leaders, who have moved to the UK from countries in other parts of the worldwide Methodist community. ${ }^{2}$ This experience of globalisation has provided opportunities for change, growth and renewal within The Methodist Church in Britain (MCB). ${ }^{3}$

My own research is responding to these changes within the UK and explores how British Methodist congregations are engaging with this wider spread and variety of ethnic diversity. My research interest comes from my commitment to the Methodist Church, which I argue has always had a particular theological and missional interest in the global relevance of the gospel across potential boundaries. In this article I use primary research to see what can be learned from those ministers working with ethnically diverse congregations (EDCs). I draw on data collected from a questionnaire (completed by 25 Methodist ministers) and from a qualitative study of interviews (with 7 presbyters) about what helps and what hinders ethnically diverse congregations in their development in this British context. ${ }^{4}$

Having established the sociological and theological context in which I am asking my research questions I first report that the theme to which the data most frequently refers is that of sharing power between people from different backgrounds. I highlight that my respondents aim to facilitate the kind of power-sharing which helps diverse members of the church to participate fully in the development of the church's life. Second, I consider the process by which the ethos of a congregation is changed to be more inclusive and participative. In particular I look at the cycle of how a church's practices change the congregation's ethos, which in turn changes the church's practices. Third, I explore the way these ministers understand the relationship between their own leadership and the ethos and practices of the churches with which they work. I argue that ministers contribute to the enabling of power-sharing, but cannot facilitate it alone.

After considering the implications of my research for the policy and practice of the Methodist Church I then conclude that the crucial factor in the healthy development of ethnically diverse congregations is the willingness to share 
power and, thus, to allow the whole body to be changed by the members who are seen as 'other' and 'different'.

\section{What is an ethnically diverse congregation (EDC)?}

It is complex to try and define EDCs because of the variety of combinations of people in the widely diverse contexts within which churches work across Britain. This huge diversity was evident in the descriptions the interviewees gave of the congregations with which they work. Sometimes the differences within a congregation derive from the cultural diversity of the countries from which members have arrived, often including different cultures of Methodism. ${ }^{6}$ Sometimes the members may all have been born in Britain but the diversity between them relates to people's home culture and the ethnic background from which their family has come. In this article I use the term EDC not simply in a descriptive sense but rather in an aspirational sense. I do not use EDC to mean a group of people who happen to be different from one another but more to describe those congregations whose communal intention is to reflect the ethnic diversity of their local community and to develop into churches that celebrate difference and enable equal and full participation of all members.

\section{Sociological background}

Globalisation is a phenomenon which has received enormous attention from geographers and sociologists and is now attracting increasing attention from theologians. ${ }^{7}$ While there is not yet any statistical analysis of the changing patterns of ethnic diversity in British Methodist congregations, recent research into the ethnic diversity of those who self-identified as Christian in the last two censuses finds that'among people of black, Asian, white European and mixed ethnicity, the number of Christians is dramatically increasing. The Global Church has now well and truly taken root in England.' The other change noted is the proportion of Christians from the non-white or white (other) categories in various regions of the country: 'All regions now have significant ethnic diversity in the Christian population, which already is having an impact on the diversity of congregations of historic denominations ... and also on the priorities for ecumenical relations, evangelism and pastoral care.' 
The research that I have carried out is a contribution to the academic conversation about the effects of globalisation, recognising that, in human geographical and sociological studies, there is a particular interest in the superdiversity and hybridity that can result from transnationalism. ${ }^{9}$ As society changes, people interact more and more naturally with each other, in some communities at least. In a globalised world, as the generations claim broader and broader heritage, the term 'ethnic' is perhaps becoming less helpful. Some scholars argue that the use of 'race' and 'multi-racial' in earlier academic work was fundamentally flawed. ${ }^{10}$ More recently, according to Stephen Jivraj,

The 'Other' ethnic group categories - 'White Other', 'Other Black', 'Other Asian,' 'Other Mixed', and 'Other' have all increased, in total by over 2 million in the last 10 years. The existing ethnic group categories are, perhaps, becoming increasingly less meaningful for many people. ${ }^{11}$

Despite these reservations it is clear from my data that, in practice, the differences between people, and the groupings which can form within congregations according to linguistic or cultural bonds of commonality, can often cause or perpetuate divisions within a church community. ${ }^{12}$ It is important, therefore, to discover how to encourage proper mutual respect and to enable full participation of different people within the same congregation's life. In a Methodist context this is particularly significant because of the heritage of wanting to witness to the ability of the Holy Spirit to reach out to all people with the gospel, and to unite different people within the one body of the Church.

\section{Theological background}

The development of good practice within EDCs is important to me personally because as a lifelong Methodist I have grown up with the conviction that the gospel is for everybody and I understand this to have clear implications for mission and ministry within the Methodist Church. There are elements within Methodist history that demonstrate an expectation of openness to difference and much within Methodist theology to commend inclusiveness as an essential commitment. The celebrated 'Four Alls' of Methodism are a later way of describing a collection of emphases that had been crucial, from the beginning of the movement, in proclaiming that the gospel is for all people. For example, 
this was put into practice, in early Methodism, by the inclusion of AfricanAmerican slaves among its group of preachers and, where the law refused this possibility, these preachers continued to preach while using the title 'exhorters'. Wesley's sermon 'The Catholic Spirit' (1755) is another illustration of his own determination to encompass all people, and Richard Clutterbuck describes a theology of interdependence as a hallmark of British Methodism. Methodist reliance on the concept and practice of 'fellowship' and an ethos of belonging locally as well as to a bigger whole are also important factors in the way that Methodism encourages participation from newly arrived members whatever their background. ${ }^{13}$

The history of the Methodist Missionary Movement is one that has developed a range of transnational relationships across many different cultures and countries. Although this missionary movement was, inevitably, affected by its colonial context, the legacy of this history is a worldwide network of Connexions. ${ }^{14}$ Over recent decades Methodists have migrated from countries to which the British Methodist Church (among others) sent missionaries. My data suggests that the challenge now is whether Methodist congregations are willing to receive from people who are arriving in this country and to be changed by their presence and participation. This challenge has to be set within the context of post-colonial theology, which always seeks to redress power dynamics and to challenge attitudes of racism or paternalism from a theological basis of respect for the equality of all people. ${ }^{15}$ This challenge is one that many churches seem reluctant to take up: in reality the opportunities that globalisation brings have not always been grasped. I hope within the current study to highlight the processes by which congregations can move towards a deeper willingness to change and to be changed.

\section{The scope of this study}

The empirical research which I undertook for this article is set within a wider piece of research which is studying in more detail theological perspectives on what geographers have termed our 'super-diverse' society. ${ }^{16}$ Due to the complete lack of ethnic monitoring for church members in the Methodist Church it is impossible to say where EDCs are distributed across the country, or to say from which ethnic background or home country church members come. The last thorough study was carried out in $1985,{ }^{17}$ and there is no doubt that the picture has changed significantly since then. Studies of population growth show, for example, that 'the African ethnic group' has grown faster than 
any other minority group since 1991, and this includes, for example, Zimbabwe and Ghana, where Methodism has a strong presence. ${ }^{18}$ In particular, the variety of countries from which Methodist members have arrived has widened. While there have been British Methodists from Caribbean Methodist churches since the 1950s and 1960s, arrivals over the last two decades, from Fiji, Ghana, South Korea, Nigeria, Sri Lanka and Zimbabwe (for example), among many other countries, have added to the variety of Methodist cultures represented among British Methodism. The arrival of these Methodists, and their ability to attract people from other cultures who have not previously been Methodist or Christian at all, has added to the diversity of many local Methodist church congregations.

Within the more recent arrivals to Britain from other countries that have their own Methodist Connexion, there are some ethnic groupings that have formed their own Fellowships within the MCB. One example is the Methodist Church Zimbabwean Fellowship, which has 43 Fellowship groups across the country. The models of networking vary from one Fellowship to another but they generally seek to operate within the MCB and to encourage their members to participate as fully as possible within it. This year's Methodist Conference received the Report of the Working Group on Fellowships, which made recommendations designed to 'bring about deeper relationships, mutual partnerships and genuine integration of Fellowship Groups within the Connexion of which they are part.'19

While the life and influence of these Fellowships are fascinating and crucial to the wider picture of ethnic diversity within British Methodism, it is, in particular, individual local ethnically diverse congregations that I have chosen to study here. I am conscious also that there are many other forms of cultural diversity, not least economic, within the British Methodist Church. However, in this piece of research I focus on EDCs. Having explained the relevance and focus of my research, and considered the context within which this research was undertaken, let me now describe the scope of this study.

\section{Methodology}

With the context of globalisation as the background, and with the questions of how to help churches diversify in the foreground, I undertook some primary qualitative research over a six-month period (from October 2014 to March 2015). 
When I designed my research I wanted to use the recognisable language of the connexional Belonging Together strategy, as it was a recent Methodist project which had reported to the British Methodist Conference. I specifically wanted to know which practices build up the sense of 'belonging together' within these congregations, and which factors make it difficult for people to feel that they 'belong together'. In wanting to reach an understanding of the experience of EDCs I am especially influenced by the work of Kwame Anthony Appiah, who argues for a 'the primacy of practice' in his study of cosmopolitan ethics, and, in theological terms, I am especially influenced by Mary McClintock Fulkerson who writes about the lived practices of a congregation and uses the work of Alasdair Maclntyre in her study of an ethnically diverse American Methodist Church. She writes: It is crucial to pay attention to the role of practices that are primarily incorporative ... remembering that it is the full-bodied social practices, not simply the beliefs and convictions from Methodism that make place. ${ }^{20}$

Considering the lack of research into the phenomenon of EDCs within British Methodism I began with a concern to identify the range and variety of experiences of EDCs. I chose, as a pilot study, to carry out a survey of Methodist ministers (lay or ordained) involved in leading EDCs across the Connexion. I chose a questionnaire as my methodology because I knew the target audience would have a high level of concern and engagement. ${ }^{21}$ I designed a selfcompletion questionnaire and as a convenience sample decided to ask for participation from the members of the Methodist City Centre Network (MCCN). ${ }^{22}$ I knew, from my involvement with MCCN over ten years, that there is a wide range of experience represented and that the majority of participating churches have experience of ethnic diversity of some kind within the congregations. The questionnaire (Appendix A) was given to the ministers who attended the MCCN conference of November 2014, where I was afforded the opportunity to introduce my research. It was subsequently sent to all the members of MCCN electronically, inviting them to respond. One unplanned snowballing effect of the electronic mailing was that the questionnaire was also sent to all the ministers within the London District. While this was not initiated by me the benefit was that it did elicit more responses from relevant ministers. By the deadline, 25 Methodist ministers (4 lay and 21 ordained, just over half female) had returned the questionnaire. The respondents represented 6 districts (Birmingham, East Anglia, London, Manchester, Northampton and Southampton) and 20 circuits of The Methodist Church in Britain. These respondents represented a good range of EDCs, from single congregations 
including more than 20 'nationalities', to 'all-white' congregations with a large proportion of South African members, and included EDCs where a small minority of the members were from Eastern European countries. The churches' histories varied from those which have been EDCs for more than 50 years to some which have diversified much more recently.

The initial questionnaire gave me some useful data, including the lists of practices which built up and which hindered the development of EDCs (see Appendix B). Once I analysed the data, using a coding method, the responses provided relevant themes that I wanted to explore further, and so I decided to follow up from the results with a qualitative study by interviewing some of the participants. ${ }^{23}$ Those I interviewed were self-selecting because I arranged to interview each respondent who indicated a willingness to talk further. These seven ministers were all women presbyters: two are not British-born and one other is Black British. ${ }^{24}$ While there was ethnic diversity among the respondents it was not a representative view that I was aiming for, rather a selection of ministers' responses from a range of EDCs. I was satisfied that the interviewees represented a range of experience with EDCs. They represented three districts (London, Northampton and Birmingham) and seven circuits. There is undoubtedly more research to be done about the experience of ethnically diverse ministers within the British Methodist Church. ${ }^{25}$ While I consider that to be outside the scope of this current study I am glad that the Methodist Church has been undertaking such research and look forward to seeing the results.

In order to deepen my understanding I chose to use semi-structured interviews, which I based upon the same open questions from the survey. This method was appropriate to this early stage of my research as it allowed the respondents to control the direction and content of their responses. I began the interviews with questions about the geography, history, demography and circumstances of the congregation and its context. My chosen method then allowed me to develop the themes that had become evident during the initial, wider survey. ${ }^{26}$

In this qualitative research I was able to probe a little further about how the ministers saw their experience of working within EDCs. The current data reflects the views of church leaders but not of other church members and this points to the need for further research into the views and experiences of other members of EDCs later. Nevertheless the focus on ministers' experience, perceptions and practice potentially enables good practice to be shared. I hope to facilitate these processes through the writing of this article. 


\section{The findings}

\section{(a) The need for power-sharing}

The open questions in my survey of ministers working with EDCs were designed so that people could express whatever they wanted about what helps and what hinders the development of such congregations. In analysing the data it became clear that the theme most mentioned by respondents was the need for 'power-sharing' within a church. ${ }^{27}$

To take a straightforward example, one interviewee described the dynamics of making decisions about the style of fundraising within the church:

There was a fundraising event going on at the church ... they needed desperately to do some renovations. The Brits wanted to do a series of fundraising events but the Koreans considered that individual events were a bit insulting. They would rather give substantially, the Koreans. For them members of the church have this responsibility and members should be asked to give. They were being disenfranchised by not being invited to give in the way that they saw as their responsibility. (Bryony)

The description here is of two different church cultures within the one congregation. The decisions on how to raise funds were made by one particular group ('the Brits'), This caused a sense of disempowerment for those from the other group ('the Koreans') who would, in their home country, approach the financial need quite differently. There has been no real consultation or joint planning and one model has been assumed by those making the decisions within the church. The 'other' group has ideas, and strong preferences, and a clear model which works elsewhere but they are not given the opportunity to contribute their thoughts and ideas. This leaves them less than enthusiastic for the task in hand and means that one group is 'disenfranchised'.

All of the interviewees expressed belief that a diverse decision-making body is the ideal model within an EDC. Nevertheless, many of the respondents commented on the difficulties that can arise from trying to make joint decisions with diverse teams, from different cultures, within the same church council or committee. As Jean said:

Having a diverse team makes for much stronger decisions ... but it is hard because you get a lot more conflict, things take a lot longer, 
and I think it's a much more frustrating experience for the people involved. (Jean)

Or as Bryony asked:

Does 'Integration' too often mean 'assimilation'? Or do the newcomers have an opportunity to offer their gifts as well (and have their gifts accepted and used)? (Bryony)

Indeed there was a common understanding between all seven ministers interviewed that it is important to find ways of building up diverse church councils and church stewards' teams ${ }^{28}$ in order to develop a sense of common purpose and vision within the Body of Christ. In seeking this diversity the ministers aim to share the responsibility of planning and decision-making.

There were some respondents to the survey who considered that the style of worship is what puts some people off from staying at a Methodist church when that style is very different from the worship they are used to in their home countries. On the other hand some ministers felt that the worship style was not as important as the experience of power-sharing in retaining new members as part of the congregation.

I believe that the style of worship has less to do with making people feel they belong, than the way people are invited and included in the activities and events that happen in a church. People need to be encouraged to take part. They are happy to worship, even if the worship is not their style, as long as they're made to feel as though they are valued. (Vanessa)

This theme of valuing people and of showing that people are valued by encouraging them to be fully participating members in the life of the church was echoed by Elizabeth:

I'm conscious that I came to a church where there was already a diverse stewardship team within the context of that particular congregation and we try and encourage people to participate even when they're new. As one person of the congregation has remarked we are a church which recognises and values people's gifts. (Elizabeth) 
The data recognises that welcoming people is a good start but does not go far towards the building up of ethnically diverse congregations. Whereas all congregations believe they are friendly and many state that 'Everybody is welcome', the reality is different. The data shows that although churches usually want new members, not least to help the church continue, they do not necessarily want the new arrivals to change anything.

Linbert Spencer comments:

\begin{abstract}
Although most organizations say that they want individuals to bring different and innovative approaches, in practice they operate on the basis that difference is of little or no value and similarity is of great importance. This is usually not conscious or deliberate, but unless deliberate and positive action is taken to recognize, acknowledge and promote the value of diversity, then the old order will prevail. ${ }^{29}$
\end{abstract}

The interviewees described some resistance to change and the high occurrence of references to the need for power-sharing among congregational life reflects that it is not always a reality. Furthermore, the ministers see this challenge as key to the change and transformation of churches so that they develop in a properly participative way to become EDCs rather than remaining as churches that include some people from different ethnic backgrounds. ${ }^{30}$

\title{
(b) A process of change
}

I have first described that the strongest theme from the data is that of powersharing. I now want to consider the process of change which the respondents describe as enabling this power-sharing to happen.

Within the data there is clear recognition that this process of changing from being a mono-cultural church, or a church which has some members from different ethnic backgrounds, to becoming a truly ethnically diverse congregation, is not an easy or quick one. My questions in the questionnaire produced, collectively, a list of the practices (customs, activities, events and ways of doing things) that contribute to the building up, or not, of EDCs. These answers were in response to practical questions but also reflect the activist and practical nature of Methodist life and theology which means that theology is often developed pragmatically rather than systematically. ${ }^{31}$ My data shows that there are many regular ecclesial practices which help with the building up of meaningful interaction and a sense of belonging together in an ethnically 
diverse congregation, but also many which have the opposite effect. There was a clear recognition among the ministers that the things churches actually do together influence and form the ethos of the congregational life. ${ }^{32}$ For example:

We organise quizzes. A group of people (or even one person) help make up the quiz about their country. This helps everybody to get more informed about a place and also makes the person who is from another country the expert, when often they are disadvantaged in some ways in other contexts, both in and outside the church. (Bryony)

Bryony was acknowledging here that the seemingly straightforwardly social practice of holding quizzes can, even if temporarily, change the power-balance within the church relationships. Her understanding was that this experience, however transitory, actually contributes to longer-term change in the way that people see themselves and others. It means that people who have been ignorant about each other's home countries become more informed and have more of a basis for conversation consequently. Additionally those who are often treated as not knowing or understanding become the ones who have the knowledge in this setting.

In relation to the pastoral care of the church Bryony also described a practice she had introduced personally to share knowledge of different customs from different Methodist cultures. When asked about what strategies she had used to encourage people to work together as effectively as possible when they are from diverse ethnic backgrounds, she answered:

Having discussions in Pastoral Committee about different styles/ expectations with regards to rites of passage; essential to have selected diverse voices in advance to present views - discussion will follow - and perhaps even some new Good practice learned and developed across the bounds of ethnicity. (Bryony)

This careful preparation for a meeting changes what happens within that meeting, to include, effectively, some informal training and to deepen understanding and relationship. ${ }^{33}$ For many respondents there was a pastoral recognition that making conversation and getting to know each other is not an easy task:

The hardest thing is that people often don't know what to ask about with other people's lives without worrying about showing themselves up as ignorant or whatever. (Ruth) 
Ministers saw it as part of their responsibility to find ways of both enabling conversation and also modelling conversation across cultures. There was a common perception among the respondents that the practices which help ethnically diverse congregations were ones which encouraged a more nuanced level of understanding of one another and provided, therefore, more opportunity for honesty of encounter and dialogue. There was an understanding that the Methodist concept of fellowship is key in relation to this aim. ${ }^{34}$ Elizabeth referred to the link between Methodist understanding of church belonging and the practice of getting to know one another well:

... our understanding of the church is that the local church should be pastorally responsible for its members and so therefore some people beyond the minister have to have some knowledge of the people. And from the small group beginnings of Methodism we have to know each other in order to assist each other in our growing discipleship. There's something in the Methodist understanding of church and being together. (Elizabeth)

I found a clear link in the interviewees' answers between helping people to get to know one another better and the belief that this will lead to more equally participative approaches within the congregation. One respondent, Bryony, described a very deliberate strategy for appointments which included using a nominations committee whose job was to get to know the congregational members well, thus enabling discernment about what strengths and gifts the most appropriate people had, regardless of their background. In other words, it was not good enough to appoint people just from within the group that you already know.

We have been on a journey of appointing people of diverse ethnicity to leadership positions. We have a nominations committee that meets between Jan-April, ready for General Church Meeting. We look at what are the talents of people, what do we need, how can we best encourage and use the gifts and graces of people. I'm gentle but insistent about this. It took 5 years to have a black steward but we have now. We have just under 200 members ... but l've done it the same way in other churches with 50 or 60 members. (Bryony)

The use of the word 'journey' here is typical of the way in which respondents saw the participation of a bigger variety of people as a process that develops 
over time. In its simplest form, what my data shows is the process whereby church practices influence congregational ethos, including the attitudes of the people, and this ethos then gradually influences the practices (Figure 1). This process is ongoing, as described by the respondents, and can build up positively (in terms of helping people to participate more fully) or negatively (in terms of leaving people unable to participate). ${ }^{35}$

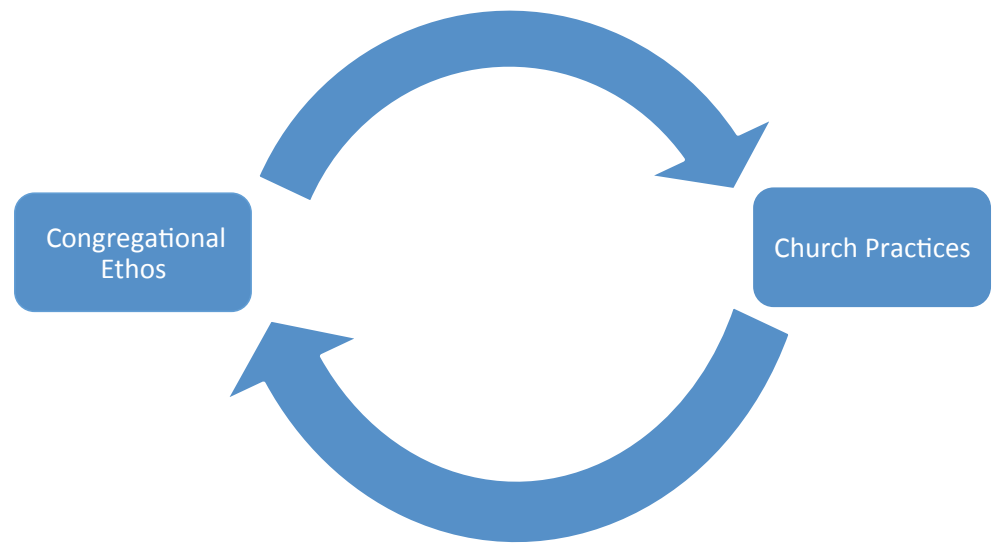

Figure 1

One regular question for ministers in an EDC appears to concern how explicit and intentional to be about these processes which are taking place continuously. This brings me to the third aspect of the data that I would like to consider, namely how ministers particularly see their own role in relation to the developing of EDCs.

(c) The minister's role in the development of ethnically diverse congregations

Interviewees all acknowledged that their role in helping to develop EDCs is one role among many roles and that, within the Methodist circuit system, ${ }^{36}$ there is an obvious need for others to be involved in this ministry of building up EDCs:

You need people, even if only one or two individuals, who are friendly and approachable and will go and do the work of engaging with the congregation including those who are new ... The leader or minister does have a role obviously, but especially in Methodism when the minister often isn't there it's the congregation which 
counts and having some people who are able to make those conversations happen over coffee. (Ruth)

Given that Methodist understanding of ministry is that of the ministry of all God's people ${ }^{37}$ and that in practice the minister cannot be present as often as the rest of the congregation then it is good that this collaborative venture, of building up EDCs, is recognised as a joint responsibility.

They are naturally a friendly group of people and I have sought to encourage and uphold that openness. Those people who have a sense of responsibility for it within the church try hard to make the best relationships they can within what's possible. There's just this willingness to embrace or to recognise that 'what I like is not the only perspective'. (Elizabeth)

Methodism sees ordained ministry as, partly, a ministry of focus and representation. My data shows that ministers recognised the need to enable others to make honest cross-cultural relationships. A significant theme in the data was an understanding that part of the minister's role is to speak out loud the tensions that others were experiencing. Jean described in detail an incident around the time of Harvest Festival in which two women came into conflict about the style of the Harvest flower display. Her response was to be explicit with them about what was occurring:

Guys, this is a cultural conflict. This is Africa meets the Caribbean. What are we going to do about this? How are we going to work it out? (Jean)

This response is assertive in making the responsibility to find a solution a joint responsibility. She is drawing attention to the nature of what is happening, naming it in a way which does not leave it unspoken and ignored, and is also challenging the women to find a way forward while counting herself along with them, rather than taking over. ${ }^{38}$ Ruth saw rites of passage as an opportunity for greater awareness of different cultural patterns and pastoral involvement from the wider congregation with that particular family. She comments:

As a minister I find that the pastoral offices for people ... are about meeting people's needs, creating holy moments, and they allow you 
into people's homes and lives. One lovely moment was when on the Harvest Sanjay was asking for something and I didn't know what it was ... and then it turned out to be a blessing for a weaning of their second baby who was going to have rice and beans for the first time. So I made up a blessing over coffee time and it was a lovely family moment. (Ruth)

She goes on, also, to show a sophisticated thinking through of the opportunity given by a baptism ceremony, which she conducted with the child's father (a Zimbabwean local preacher) in both Shona and English. She made a conscious choice not to have all the Shona translated:

I felt it gave an extra significance to the Shona language (for some of it to stand alone without translation) and also it put people into the position of thinking what it would be like for the others not to understand ... and it meant we had to trust each other that 'we don't know what else is going on but we believe holy things are going on here'. That was good for everybody. (Ruth)

This explicit use of the liturgy to involve the whole congregation in the bilingual lives of the family echoes some of the other respondents' narratives about creating opportunities for people to empathise more easily with the experiences of others in the congregation.

The data gives examples of respondents finding that their own views and assumptions are challenged along with other people's, by the presence of ethnic diversity within the congregation. Ruby, for example, was clearly including herself in the number of people who found time-keeping differences difficult.

I find it refreshing but it can cause tensions ... the time thing, for example ... one couple rarely come on time, but that is just how it is. It's just we recognise that this is what happens and they accept it. People recognise that it's part of their culture and if they want to embrace them ... then they need to be valued as part of their community. (Ruby)

Ministers recognised that they were there to work with a congregation and that this congregation had a life of its own, which they could influence but not determine alone. There was also recognition that their particular role gives 
them a specific responsibility to influence congregational practice and ethos, and also that it gives them the possibility of doing this. This dynamic could be shown in the diagram by adding the influence of the ministers through their input to the church practices and also, therefore, to congregational ethos (Figure 2).

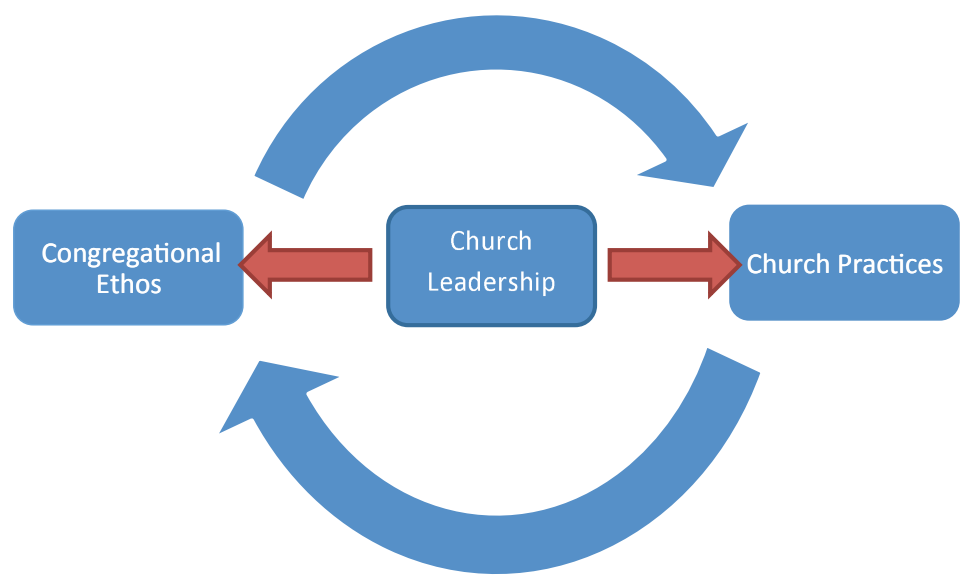

Figure 2

The ministers interviewed see their role as one of modelling positive relationships, which includes willingness to be changed through the encounter with different people. Included within this role is the sharing of power with others, which illustrates Methodist theology of collaborative leadership and ministry. ${ }^{39}$ So what are the implications of this research for Methodist policy and practice?

\section{Implications for Methodist policy and practice}

The Belonging Together project of The Methodist Church in Britain (20102013) had two aims:

- The affirmation of culturally diverse churches, groups and individuals within the Connexion, and creating an environment in which they can be themselves, enjoy meaningful interactions, and take full advantage of Connexional structures and resources; and

- The creative interaction within the Connexion of groups and individuals of culturally different backgrounds, whereby they can contribute positively to the ministry of the whole people of God, locally and connexionally, and receive gifts and experiences from each other. 
At the end of this three-year project, in the final report of this project to Methodist Council (2013), there was a conclusion:

What Belonging Together has demonstrated is that ethnic inclusion cannot be left to chance or choice, nor indeed be reduced to quotas or compliance. This agenda will need to be owned and championed at all levels of Church governance and leadership, and of fellowship and meaningful interaction across the Connexion.

My research shows that the decisive factor in the development of ethnically diverse congregations is the willingness of all those involved to allow the whole body to be changed by those who are 'other' and 'different'. Despite a commitment for the whole Church to aim for 'affirmation' of cultural diversity, and to value 'meaningful' and 'creative interaction', this will not happen unless the MCB is willing to be changed by the diversity that it now experiences. The $M C B$ 's previous history of positive racism awareness training will continue to be crucial and the Belonging Together strategy needs to be set alongside postcolonial theology with its challenge to redress power dynamics. ${ }^{40}$ The end of the project report for Belonging Together stated:

Valuing all means enabling all to participate in the whole spectrum of activities and roles found in our Church. This may mean that in some areas the status quo will need to be challenged and that positive action may need to be taken to ensure the outcomes that give due respect to all in our communities. ${ }^{41}$

My research suggests that such positive action is possible through changes to current lived practices within local congregations. Although this study focuses on local congregations I suggest that the same dynamics could be present at connexional level and the suggestion to include representatives of the ethnically or linguistically specific Fellowship Groups at District Synod and at the British Methodist Conference would be one small but significant way of working towards redressing the current power inbalance. ${ }^{42}$ Continued commitment to making positive changes and to challenging the status quo in some areas within the MCB is welcome. Some measure of checking the current power dynamics and the direction of change needs to be built into the Church at every level. 


\section{Conclusion}

Spencer comments, 'The difficulty institutions have is one of failing to understand the difference between allowing people to participate, and actively seeking the participation of those who are not already participating. ${ }^{\prime 43}$

The interviewees showed that they were aware of the need for power to be shared equitably, to involve all those who have a part to play, however small their part may be. They demonstrated sometimes quite sophisticated understanding and skill in facilitating learning and empathy within the congregation so that different people could understand each other more deeply. The data showed an awareness of the need to name and challenge any negative dynamics within EDCs that resisted change or equality, and threatened the holiness of the church:

It has been important to be outspoken about issues of racism and justice and to pick up any issues between people within the congregation so that they didn't 'fester'. I felt as though my role as minister was partly to enable this to happen. (Julie)

In examining the data carefully it was clear that some of the positive practices existed before the minister in question arrived at the church concerned, and some were deliberately introduced by the minister. The respondents recognised that the congregation had a life and ethos of its own. The data showed not only that the minister was influencing the development of the congregation by what they challenged or what they encouraged, but also that they were being changed themselves, and in their leadership, by their engagement with the life of the congregation.

My earlier diagram can, therefore, be adapted in order to show that the ministers' influence upon the development of EDCs comes through their modelling, suggesting, challenging and encouraging of different practices, but also, significantly, by their willingness to be changed by others in the process (Figure 3).

The willingness, or lack of willingness, of the congregation to be changed by those who are from outside extends to the willingness, or lack of willingness, to be changed by the contributions of a minister, who in an itinerant system has arrived from beyond the congregation. Therefore the power to resist or to embrace the minister's influence lies with the congregation. Similarly the 


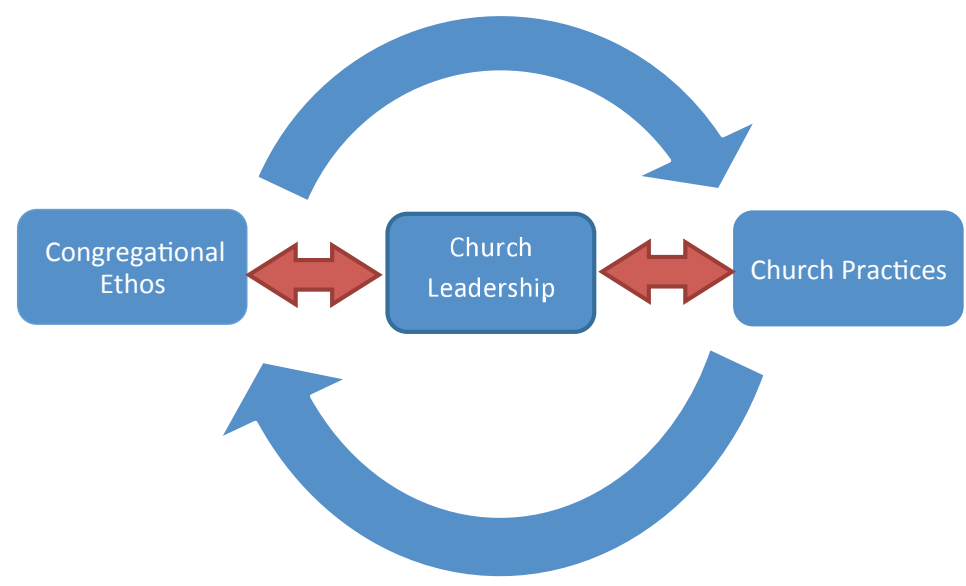

Figure 3

minister's willingness to be changed by the life of the church influences his or her ability to influence the congregation.

In order to raise awareness of the dynamics that are at play across the MCB my research suggests that it would benefit the Church to develop a way of measuring the participation of a variety of people within congregations, circuits, districts and connexionally. More detailed ethnic monitoring would go some way towards this but a scale for measuring the sharing of power would also help British Methodists to become aware of the distance which still needs to be travelled. ${ }^{44}$ For The Methodist Church in Britain to become a genuinely ethnically diverse church I suggest that the Methodist Conference needs to aim for each and every level and grouping of Methodists to become intentionally an ethnically diverse community of people, in order to reflect the glory of God and the possibility of the gospel being proclaimed to all people.

\section{Appendix A}

\section{Survey questions}

Please answer this set of questions for each ethnically diverse church that you work with.

1. Thinking of the ethnically diverse church that you are working with... What have you noticed that contributes positively to helping people feel as though they 'belong together'? 
2. Thinking of the ethnically diverse church that you are working with... What have you noticed that makes it hard for people to have a sense that they 'belong together'?

3. Thinking as broadly as possible, what strategies (if any) have you used to encourage people within the church to get to know each other better when they are from diverse ethnic backgrounds?

4. Thinking as broadly as possible, what strategies (if any) have you used to encourage people within the church to work together as effectively as possible when they are from diverse ethnic backgrounds?

5. Please describe to me any other concerns or comments that you have about these issues, in as much, or as little, detail as you would like.

\section{Appendix B}

1. Practices which help development of ethnically diverse congregations

Quizzes on one particular country where the 'experts' from that country set the questions, often to include questions about Methodism in that country.

Food evenings ... it was felt that this was often better for one country's cuisine.

Preaching and prayers to include an emphasis on inclusiveness, and the theme of being one body in Christ.

Learning new songs from other countries.

Including diversity in leadership teams and decision-making bodies.

'Knowing me, knowing you' sessions.

Conversation in worship as part of the sharing with one another.

Modelling the possibility of chatting to different 'groups', eg at meals or coffee times.

Including different voices and accents in worship.

Trying different styles of worship or different customs, eg one church which asked the African members to arrange Harvest, and all the customs that go with it, from their home country. 


\section{Jill Marsh}

Using other languages in worship: in prayer, Bible readings, rites of passage. Phonetic spelling of names when first told them ... to make remembering easier.

Photo gallery with names underneath so people can 'go back' and check.

Extending the 'sharing of the peace' to a conversation about a particular topic.

Sermon illustrations from different cultures and places.

Using the General Church Meeting for conversation on a Sunday, after or during worship.

Welcomers who are trained in the greeting of new people and in checking out whether they expect to be given opportunity to introduce themselves (as in many other countries).

Newcomers' lunches held regularly for any new people to develop friendships. Encouraging home hospitality from the members.

Being explicit and outspoken in challenging any discrimination or 'oversight' of people who are not naturally part of the current 'circle' of the church's life.

Challenging differences of opinion in a relaxed way.

Examining different clashes of opinion or approach and encouraging others to see this as acceptable and helpful in getting to know and understand one another better.

Going to social things together, eg football matches, the pub, or outings.

Making sure that planning groups or task groups are jointly held with people of different backgrounds working together on things.

Art and crafts together.

Having fun!

Prayer groups which encourage everybody to be involved and to care for one another in this way, sometimes within the worship.

Pooling of costs for events so that people can afford to come irrespective of their economic situation.

Name badges to help people get to know one another's names. 
Making policies and procedures clear and transparent so that they are equally accessible by everybody.

'All congregation' meetings where issues and decisions are discussed with everybody who is at worship.

Interactive services where people's opinions are shared, heard and valued.

Careful use of language.

Use of image as well as of words.

Shared leadership and common goals and vision for the church.

Inclusive retreats.

Seminars on inclusivity.

Racial Justice Sundays where ethnically different people participate.

Common tasks and responsibilities in the church, eg kitchen duties, inclusive church comittees where individual gifts and graces are embraced, affirmed, utilised and celebrated.

Games ensuring each team is drawn from a diverse ethnic mix, eg volley ball. Conscientising members to be as inclusive as possible in electing people to church leadership.

\section{Practices which hinder development of ethnically diverse} congregations

Making assumptions, rather than asking, checking things, or getting to know one another.

'Niceness': not wanting to offend people.

'Mother tongue' use creating 'groups' or cliques in coffee time and at social events.

Trying to stick to the same customs and practices as previously despite new opinions and contributions.

Getting names wrong and not making the effort to remember where people are from.

Not recording decisions properly. 
Not being clear about processes and policies so that there is lack of transparency.

Giving grants to those who have the confidence to speak up in Circuit Meetings.

Domineering attitudes and behaviour of certain groups or individuals over others.

\section{Notes}

1. See Jivraj 2012, or Rees and Butt 2004, for helpful summaries of the changes in the diversity of British population 1991-2011, and Rees et al. 2012 for population projections into the future.

2. The Methodist Church does not have ethnic monitoring data for Methodists arriving in Britain from other countries where Methodism is strong. However, studies of population growth (see Kyambi 2005 and Jivraj 2012) show, for example, that what they call 'the African ethnic group' has grown faster than any other minority group since 1991, and this includes Zimbabwe and Ghana, where Methodism has a strong presence.

3. There is currently ethnic monitoring data within the Methodist Church for ministers and for delegates to Conference but not for church membership or attendance, nor for trustees' meetings. There is therefore a need for this research to be done and the Methodist Church is working on how to put this into practice. See also Walton 1985, Davey 1988, and Frost and Jordan 2006, for literature about the experience and impact of ethnic diversity within The Methodist Church in Britain.

4. I am using the term ministers here to refer to church leaders, either ordained or lay. EDC is a shorthand for ethnically diverse congregations. It is my own abbreviation and is defined later in the article. Presbyter is the name used for those who have traditionally been known as 'ministers' within The Methodist Church in Britain. They are ordained to the ministry of word and sacrament. Some ordained deacons (the other order of ordination within the MCB) were also invited to take part in the survey, as well as lay people, but did not choose to respond. An inquiry about the reasons for this lies outside my current research but could be rectified at a later date.

5. For an exposition of practical theology in relation to the experience of 'Otherness', see Veling 2005, pp. 98-114.

6. Membership of a Methodist church has a technical meaning according to whether or not people are confirmed and committed members willing to be on a membership list. At this point, however, I simply mean people who are part of the congregations, either as members or attenders.

7. Baker 2007, Nausner 2004, and very recently Brazal and Guzman 2015, are examples of this field of study. 
8. Council for Christian Unity 2014, pp. 1 and 24.

9. See, for example, Cohen and Toninato 2010 on creolisation, Vertovec and Cohen 1999 on diaspora and transnationalism, Ghorashi 2004 on the effects of diaspora and transnationalism on identity formation, and Nowicka and Rovisco 2009 on cosmopolitanism.

10. Bayart 2005 and Leech 2005 both make this case well in different academic fields.

11. Jivraj 2012, p. 1.

12. There is excellent work by Day and Rogaly 2012 (p. 77) about the various uses of the word 'community' which can sometimes be used to mask conflict and diversity.

13. The set of 'Four Alls' (all need to be saved, all can be saved, all can be saved to the uttermost, and all can know they are saved) is a crucial set of statements, used as the basis of Methodist theology and mission. They were named the'Four Alls' from the early twentieth century (see Turner 2002, pp. 75-76). Weems Jr 1999, p. 64, describes the work of 'exhorters' as a phenomenon of Methodist history. On the Catholic spirit, see Waller 1988, pp. 145-156. For an exploration of Methodism's theology of interdependence, see Clutterbuck 2004, pp. 59-69; for Methodism's concept of membership and connectedness see Drake 2004, pp. 131-142.

14. Connexion is the word which Wesley used for the national organisation linking Methodists to one another, and is also used now in each country's organisation of Methodists: see Clutterbuck 2004, pp. 59-69. See Davey 1988, or Frost and Jordan 2006, or Plant 1999, pp. 119-130, for a history of the interlinking between Methodism's missionary history and its current global presence in Britain.

15. For post-colonial theology, see Keller, Nausner and Rivera 2004, or Joy and Duggan 2012, or, in the context of congregational work, Sharp 2013. For an overwhelmingly convincing account of the need for intercultural pastoral theology based on post-colonial principles, see Lartey 2006.

16. See for example Wessendorf 2013, or Valentine and Sadgrove 2013, for literature around the lived experience of the phenomenon of super-diversity from a geographical perspective.

17. Walton 1985.

18. For the latest thorough literature surveying ethnic diversity in British Methodism, see Walton 1985. For figures on the more recent population trends, see Kyambi 2005, and Jivraj 2012.

19. For more information on where these Fellowships are within Britain, see www.methodist.org.uk/links/church-webmap-advanced-version

20. See Appiah 2006, pp. 69-86, and McClintock Fulkerson 2007, p. 85.

21. Gilbert 2008, p. 186.

22. This is a nationwide organisation which attracts ministers from a variety of cities and large towns.

23. I coded my themes using methodology as described by Mason 2008, ch. 8 .

24. This fascinating fact is not one that I have been able to investigate in my current study. There are certainly male presbyters working with EDCs and in fact nearly 
half of the ministers who replied to the survey were male. It could be that the seven women presbyters responded in some positive way to my covering letter, perhaps wanting to encourage a woman student. On the other hand it could be that there is a gender dynamic here that means that women are more likely to investigate the relationships and processes involved in EDCs. This statistic (though obviously from a very small sample) could be related to the feminist interest in post-colonial theology and would benefit from further research. See Pui-Lan 2005 for an exposition of the relationship between post-colonialism and feminist theology.

25. As acknowledged during the Belonging Together process.

26. Gilbert 2008, p. 193, and Bryman 2012, p. 472.

27. My current research did not allow time for following this up with questions about the significance of the theological training received by these ministers. The seven interviewees were all trained within a 15-year period from 1990 to 2005 and those respondents to the survey were trained over a 36-year period from 1973 to 2009. Nevertheless I would be interested to know whether the seven interviewees were particularly influenced by post-colonial or liberation theology which would put the emphasis on liberation from domination or from colonial bias. This strand of theology has, in my view rightly, been a significant emphasis within some ministerial training over the last 30 years. There has also, as mentioned already, been a strong emphasis within the Methodist Church on racism awareness, racial justice and anti-racism training as part of its commitment to the equality of all people. See Reddie 2009, pp. 37-52.

28. In The Methodist Church in Britain the church council members are the trustees and the church stewards effectively act as an executive team between Church Council meetings, often forming a leadership team with the minister and sometimes other officers (for example the treasurer).

29. Spencer 2007, p. 92.

30. Sheffield includes a practical diagram to help ministers assess how far their churches are along this continuum of transformation $(2005$, p. 85).

31. For an exploration of this, see Glasson in Marsh et al. 2004, and also Shier-Jones 2005.

32. Forty-one different practices were listed as having a positive effect (ranging from quiz evenings, to pooling the cost of events, to conversation challenging differences of opinion, to including different languages and accents in worshipleading). Nine different practices were listed as having a negative effect (ranging from failure to insist on legally required procedures, to getting names wrong, to using 'mother tongue' to create cliques, to discrimination in the way grants are awarded).

33. Reddie argues for this kind of informal theological training to challenge racism (2009, p. xviii).

34. For an exploration of the experience of fellowship within Methodist tradition, see Clive Marsh, in Craske and Marsh 1999, pp. 100-114.

35. This relates to the work of Baker 2007 and 2011, and Marti 2010, about the actual 
ways in which people belong to churches and then gradually become part of those churches by participation in their activities.

36. The circuit preaching system means that some ministers will only be present in each church once a month.

37. As set out in the Methodist Church report, Called to Love and Praise.

38. This narrative is a good example of what McClintock Fulkerson calls'a frame for appearing' in postmodern place theory (2007, pp. 24-48, 231-254).

39. A dynamic which it could be argued happens anyway with any congregation in an itinerant system. This feature of Methodist ecclesiology would benefit from further study of this aspect of practical theology in relation to the development of congregations in super-diverse and super-mobile areas.

40. For one example of the racial justice strategy documents produced by the MCB, see The Methodist Church 2005.

41. The Methodist Church's Belonging Together project ran from 2010 to 2013.

42. A strategy suggested by the Report of the Working Group on Fellowship Groups to the British Methodist Conference 2015.

43. Spencer 2007, p. 11.

44. While statistical monitoring will have a part to play here I am thinking more of a measuring tool that churches could use as a way of checking out with each other whether all people feel recognised, known and empowered within the church or not. This tool could perhaps then be used annually in the same way that property and safeguarding reports are required to be done annually. Leaving the responsibility of this to 'everybody' risks the possibility that 'nobody' will take the responsibility seriously and so the appointment of a circuit 'Diversity Officer', just as circuit 'Safeguarding Officers' are appointed for the same reason, might be another possible measure to take. The challenge will still need to come from outside congregations and training for this will continue to be important. However, the desire to change is what needs encouragement and I hope that the understanding of the processes of change (based on practical theology and the recognition of the importance of practice) from this article will help to encourage churches along the road to becoming EDCs.

\section{Bibliography}

Appiah, Kwame Anthony. 2006. Cosmopolitanism: Ethics in a World of Strangers. London: Penguin.

Baker, Chris. 2007. The Hybrid Church in the City - Third Space Thinking. 2nd edn, London: SCM Press.

Baker, C. 2011. Introducing 'Spiritual Progression in Economic Recession' Conference, 17th March. William Temple Foundation (retrieved from iTunes, 4 January 2014).

Bayart, Jean-François. 2005. The Illusion of Cultural Identity. 2nd edn, London: C. Hurst $\&$ Co.

Brazal, Agnes M. and De Guzman, Emmanuel S. 2015. Intercultural Church: Bridge of Solidarity in the Migration Context. Borderless Press. 
Bryman, A. 2012. Social Research Methods. 4th edn, Oxford: Oxford University Press. Clutterbuck, Richard. 'Theology as Interaction: Ecumenism and the World Church', in Marsh, Clive, Beck, Brian, Shier-Jones, Angela and Wareing, Helen (eds). 2004. Unmasking Methodist Theology. London and New York: Continuum, pp. 59-69.

Cohen, Robin and Toninato, Paola. 2010. The Creolization Reader: Studies in Mixed Identities and Cultures. Abingdon: Routledge.

Council for Christian Unity. 2014. Changes in the Ethnic Diversity of the Christian Population in England between 2001 and 2011. London: The Church of England.

Craske, Jane and Marsh, Clive. 1999. Methodism and the Future: Facing the Challenge. London: Cassell.

Davey, Cyril. 1988. Changing Places: Methodist Mission Then and Now. Basingstoke: Marshall Pickering.

Day, Abby and Rogaly, Ben. 2014. 'Sacred Communities: Contestations and Connections', Journal of Contemporary Religion 29(1): 75-88. DOI: 10.1080/ 13537903.2014.864806 (retrieved 25 June 2014).

Drake, Philip. 'Joining the Dots: Methodist Membership and Connectedness', in Marsh, Clive, Beck, Brian, Shier-Jones, Angela and Wareing, Helen (eds). 2004. Unmasking Methodist Theology. London and New York: Continuum, pp. 131-142.

Frost, Brian and Jordan, Stuart. 2006. Pioneers of Social Passion: London's Cosmopolitan Methodism. Peterborough: Epworth Press.

Fumanti, Mattia. 2010. "Virtuous Citizenship": Ethnicity and Encapsulation among Akan-Speaking Ghanaian Methodists in London', African Diaspora 3(1): 13-42.

Ghorashi, Halleh. 2004. 'How Dual is Transnational Identity? A Debate on Dual Positioning of Diaspora Organizations', Culture and Organization 10(4) (December): 329-340.

Gilbert, Nigel. 2008. Researching Social Life. London: Sage Publications.

Glasson, Barbara. 'Stories and Story-telling: The Use of Narrative within Methodism', in Marsh, C., Beck, B., Shier-Jones, A. and Wareing, H. (eds). 2004. Unmasking Methodist Theology. London and New York: Continuum.

Jivraj, Stephen. 2012. 'How has Ethnic Diversity Grown 1991-2001-2011?' Economic and Social Research Council. www.ethnicity.ac.uk (retrieved 14 June 2015).

Joy, David and Duggan, Joseph F. (eds). 2012. De-colonizing the Body of Christ: Theology and Theory after Empire. New York: Palgrave Macmillan.

Keller, Catherine, Nausner, Michael and Rivera, Mayra (eds). 2004. Postcolonial Theologies: Divinity and Empire. St Louis, MO: Chalice Press.

Kyambi, Sarah. 2005. Beyond Black and White: Mapping New Immigrant Communities. London: Institute for Public Policy Research.

Lartey, Emmanuel Y. 2006. Pastoral Theology in an Intercultural World. Peterborough: Epworth Press.

Leech, Kenneth. 2005. Race: Changing Society and the Churches. London: SPCK.

Marsh, Clive, Beck, Brian, Shier-Jones, Angela and Wareing, Helen (eds). 2004. Unmasking Methodist Theology. London and New York: Continuum.

Marti, G. 2010. 'The Religious Racial Integration of African Americans into Diverse Churches', Journal for the Scientific Study of Religion 49(2): 201-217.

Mason, Jennifer. 2002. Qualitative Researching. 2nd edn, London: Sage Publications. 
McClintock Fulkerson, Mary. 2007. Places of Redemption: Theology for a Worldly Church. Oxford: Oxford University Press.

The Methodist Church. 1999. Called to Love and Praise. Peterborough: Methodist Publishing House.

The Methodist Church. 2005. Building a Racially Inclusive Methodist Church: A Training Strategy. London: Trustees for Methodist Church Purposes.

The Methodist Church. 2013. Belonging Together - Leaving a Legacy, Embedding the Ethos. Report to Methodist Council: MC/13/43.

Nausner, Michael. 'Homeland as Borderland', in Keller, C., Nausner, M. and Rivera, M. (eds). 2004. Postcolonial Theologies: Divinity and Empire. St Louis, MO: Chalice Press, pp. 118-132.

Nowicka, Magdalena and Rovisco, Maria. 'Making Sense of Cosmopolitanism', in Nowicka, M. and Rovisco, M. (eds). 2009. Cosmopolitanism in Practice. Farnham: Ashgate.

Plant, Stephen. 'Love the most distant': The Future of British Methodism in a World Church Perspective', in Craske, Jane and Marsh, Clive (eds). 1999. Methodism and the Future: Facing the Challenge. London: Cassell.

Pui-Lan, Kwok. 2005. Postcolonial Imagination and Feminist Theology. Louisville, KY: Westminster John Knox Press.

Reddie, Anthony. 2009. Is God Colour-blind? Insights from Black Theology for Christian Ministry. London: SPCK.

Rees, Phil and Butt, Faisal. 2004. 'Ethnic Change and Diversity in England, 1981-2001, Area 36(2): 174-186.

Rees, Phil, Wohland, Pia, Norman, Paul, Boden, Peter. 2012. 'Ethnic Population Projections for the UK, 2001-2051', Journal of Population Research 29(1): 45-89. Published online 4 January 2012: Springer Science \& Business Media B.V. 2012.

Sharp, Melinda A. McGarrah. 2013. Misunderstanding Stories: Towards a Post-colonial Pastoral Theology. Eugene: Wipf and Stock.

Sheffield, Daniel. 2005. The Multicultural Leader: Developing a Catholic Personality. Toronto: Clements Publishing.

Shier-Jones, Angela. 2005. A Work in Progress: Methodists Doing Theology. Peterborough: Epworth Press.

Spencer, Linbert. 2007. Building a Multi-ethnic Church. London: SPCK.

Turner, John Munsey. 2002. John Wesley: The Evangelical Revival and the Rise of Methodism in England. Peterborough: Epworth Press.

Valentine, Gill and Sadgrove, Joanna. 2013. 'Biographical Narratives of Encounter: The Significance of Mobility and Emplacement in Shaping Attitudes towards Difference', Urban Studies 51(9): 1979-1994.

Veling, Terry A. 2005. Practical Theology: 'On Earth as It Is in Heaven'. New York: Orbis Books.

Vertovec, Steven and Cohen, Robin. 1999. Migration, Diasporas and Transnationalism. Cheltenham: An Elgar Reference Collection.

Waller, Ralph. 'The Catholic Spirit: The Need of our Time', in Jones, Ivor H. and Wilson, Kenneth B. (eds). 1988. Freedom and Grace. Peterborough: Epworth Press, pp. 145-156. 
Walton, Heather. 1985. A Tree God Planted: Black People in British Methodism. Nottingham: Ethnic Minorities in Methodism Working Group.

Weems Jr, Lovett H. 1999. Leadership in the Wesleyan Spirit. Nashville, TN: Abingdon Press.

Wessendorf, Suzanne. 2013. '"Being open, but sometimes closed". Conviviality in a Super-diverse London Neighbourhood', European Journal of Cultural Studies 17(4): 392-405.

\section{Websites}

www.methodist.org.uk/links/church-webmap-advanced-version (retrieved 24 September 2015).

www.methodist.org.uk/media/1682917/conf-2015-39-Report-of-the-Working-Groupon-Fellowships-Groups.pdf (retrieved 25 September 2015). 